\title{
Evaluation of Awareness of Cervical Cancer and Pap Spear Test of Working Women by Health Belief Model
}

\section{Çalışan Kadınların Rahim Ağzı Kanseri ve Pap Smear Testi Farkındalıklarının Sağlık İnanç Modeli Ölçeği ile Değerlendirilmesi}

(i) İlgün ÖZEN ÇINAR, id Ebru KARA

Pamukkale University Faculty of Nursing, Department of Public Health Nursing, Denizli, Turkey

\section{ABSTRACT}

Objective: The aim of the study was to identify awareness and beliefs of working women regarding cervical cancer and Pap smear test.

Methods: The data of the study designed in sectional and descriptive style were collected between June-August, 2017. The study was conducted on a total of 120 married women with no cervical cancer history, who were working in the Provincial Tax Directorate and volunteered to participate in the research. Forms containing identifying information about women and Health Belief Model scale for Cervical Cancer and Pap smear test were used.

Results: The mean age of the women was $39.5 \pm 9.02$ years and $59.2 \%$ of them had undergone a Pap smear test. Sub-dimensional score averages of the working women were at medium level. While cervical cancer sensitivity score was found to be higher in women with familial history of cervical cancer and in those with higher levels of income, Pap smear benefit and motivation score was found to be higher in women who had sufficient knowledge about early diagnosis methods $(\mathrm{p}<0.05)$. While women's knowledge on gynecologic cancer and gynecological examinations increased Pap smear behavior by three times on average, women's age increased pap smear behavior by about one fold.

Conclusion: Women with a high level of education did not have sufficient knowledge about cervical cancer. Pap smear test benefit, sensitivity, seriousness and health motivation score averages of these women should be elevated and their barrier perception score average should be decreased. Training of working women at workplace should be supported.

Keywords: Cervical cancer, Pap smear, health belief model, women cancer

\section{ÖZ}

Amaç: Çalışmanın amacı, çalışan kadınların rahim ağzı kanseri ve Pap smear test ile ilgili inançlarını ve farkındalıklarını belirlemektir.

Yöntemler: Kesitsel ve tanımlayıcı tipteki bu çalışmanın verileri Haziran-Ağustos 2017 tarihleri arasında toplanmıştır. İl merkezindeki Vergi Dairesi Başkanlığı'nda çalışan, evli, rahim ağzı kanseri öyküsü olmayan, araştırmaya katılmayı gönüllü kabul eden toplam 120 kadın ile çalışma tamamlanmıştır. Verilerin toplanmasında, kadınları tanıtıcı bilgi formu ve Rahim Ağzı Kanseri ve Pap Smear Testi Sağlık İnanç Modeli ölçeği kullanılmıştır.

Bulgular: Kadınların yaş ortalaması 39,5 $\pm 9,02$ yıldır ve \%59,2'si Pap smear testi yaptırmıştır. Çalışan kadınların ölçeğe ait alt boyut puan ortalamaları orta düzeyde belirlenmiştir. Rahim ağzı kanseri duyarlılık puanı, ailesinde rahim ağzı kanseri öyküsü olan ve gelir durumu fazla olanlarda yüksek iken, Pap smear yarar ve motivasyon puanı, erken tanı yöntemleri bilgisi yeterli olanlarda daha yüksektir $(\mathrm{p}<0,05)$. Kadınların Pap smear yaptırma durumunu, erken tanı bilgileri ve jinekolojik muayene yaptırmaları ortalama üç kat, yaşları ise yaklaşık bir kat etkilemiştir.

Sonuç: Eğitim düzeyi yüksek kadınların rahim ağzı kanser bilgileri yeterli değildir. Bu kadınların Pap smear testi yararlılık, duyarlılık, ciddiyet ve sağlık motivasyonu puan ortalamaları yükseltilmeli, engel algısı puan ortalamaları ise düşürülmelidir. Çalışan kadınların iş ortamlarında eğitim almaları desteklenmelidir.

Anahtar Sözcükler: Serviks kanseri, Pap smear, sağlık inanç modeli, kadın kanseri
Address for Correspondence: ilgün ÖZEN ÇINAR, Pamukkale University Faculty of Nursing, Department of Public Health Nursing, Denizli, Turkey

E-mail: iocinar@pau.edu.tr ORCID ID: orcid.org/0000-0002-2131-0329
Received: 06.02.2019

Accepted: 03.09.2019

Cite this article as: Özen Çınar İ, Kara E. Evaluation of Awareness of Cervical Cancer and Pap Spear Test of Working Women by Health Belief Model. Bezmialem Science 2020;8(2):113-9. 


\section{Introduction}

Cervical cancer is a cancer that has a screening program within gynecologic cancers and is therefore preventable. However, it is an important cause of death in developing and underdeveloped countries $(1,2)$. Cervical cancer is the second most common cancer among women in the world, and is the fourth most common cancer among all cancers. It accounts for $7.5 \%$ of deaths due to cancer in females, with a total of 528,000 new cases in 2012 (3). In Turkey, it is ranked fourth among women's cancers and tenth among all cancers seen in women. The incidence of cervical cancer in the 25-49 age group is higher than in other age groups (3.6\%) (4).

Human papillomavirus (HPV) is a very common virus group in the world and is the most obvious cause of cervical cancer. There are more than 100 types of HPV. In particular, type 16 and 18 HPV causes $70 \%$ of cervical cancer and precancerous cervical lesions. The Pap smear test has been the standard method in cervical cancer screening. It reduces incidence by $60-90 \%$ and mortality by $90 \%$ (2). Our country has changed national screening standards since 2013 (5). National screening standards recommend screening with cytology or HPV DNA testing once every 5 years between the ages of 30-65 (6). With cervical cancer screening, precancerous lesions can be easily detected and treated. In developed countries, $80 \%$ of cervical cancers are prevented by early diagnosis and treatment. In developing countries, this situation is reversed (2). In recent studies in our country, it is stated that the frequency of screening with Pap smear test is still not sufficient and that these rates vary between $21.9 \%$ and $50 \%$ (7-10).

The Health Belief Model (HBM) is often used in explaining preventive health behaviors. The Model argues that an individual's health behaviors will be influenced by their beliefs, values and attitudes, and is often used to explain early diagnosis and screening behaviors of breast and cervical cancer. Socio-demographic variables, psychological characteristics and structural factors are important in behavior change (11). A study found a strong relationship between cervical cancer screening practices and healthy lifestyle behaviors. In addition, women who were working were found to have lower Pap smear barrier scores on cervical cancer and Pap Smear test of Health Belief Model scale compared to women who were not working (8). Moore et al. (12) found that information about cervical cancer was not sufficient in women with high levels of education. In another study, women with a history of Pap testing had higher sensitivity, utility, severity, and perceived barriers scores than women without a history of Pap testing (12). In the literature, there were studies in which the characteristics of women's education and work status were not separated and they were compared. The aim of this study was to evaluate working women who had high educational level and to determine the health beliefs and practices of these women for cervical cancer and screening and to determine the factors that affected them.

\section{Methods}

This descriptive and cross-sectional study was conducted in a Presidency of Tax Office located in a provincial center. The universe of the research was made up of 132 married women working in the Tax Office. The study was completed with a total of 120 women. The data were collected between June and August 2017. Inclusion criteria were: Working in the presidency of Tax Office, being 18 years old or over, being married, not diagnosed as having gynecologic cancer and volunteering to participate in the study.

\section{Data Collection Tools}

The data was collected using a "Descriptive Data Form" and a "Cervical Cancer and Pap Smear Test Health Belief Model scale".

Descriptive information form; this form was created by researchers scanning the literature (8-10). The form consisted of 20 questions. These questions included women's socio-demographic characteristics (age, education, income, smoking), cervical cancer risk factors, cervical cancer and Pap smear test information, application questions and family history of cervical cancer.

The Cervical Cancer and Pap Smear Test Health Belief Model scale was developed by Güvenç et al. (13) based on Champion's HBM. The scale determines women's beliefs about cervical cancer and Pap smear testing. The likert-type scale with 5 options consists of 35 items and five sub-dimensions. The sub-dimensions are; Pap smear benefit and motivation [minimum-maximum (min$\max )=8-40]$, Pap smear barriers $(\min -\max =14-70)$, cervical cancer (CC) seriousness ( $\min -\max =7-35)$, CC sensitivity (min$\max =3-15)$, and CC health motivation ( $\min -\max =3-15)$. In this likert-type scale, each part is scored from 1 to 5 as; "strongly disagree" (1), "disagree" (2), "neutral" (3), "agree" (4), "totally agree" (5). Each dimension is evaluated separately. There is no total scale score. As scores increase, sensitivity, caring and health motivation increase; benefits for benefit perception, barriers for obstacle perception are perceived high. Sub-dimensions other than the barrier perception sub-dimension are positively correlated with Pap smear screening behavior. Cronbach's Alpha coefficients range from 0.62 to 0.86 for five sub-dimensions (13). In this study, Cronbach's Alpha coefficients were between 0.79 and 0.94 .

\section{Data Collection}

The data were collected by researchers using a face-to-face interview technique. Between July and August 2017, women were reached during working hours. Women with reports $(5$ people) and those who did not want to participate (9 people) were not included in the study. The answering time of the questionnaire took about 10-15 minutes.

\section{Ethics Approval}

Approval was obtained from the Non-interventional Clinical Research Ethics Committee of a University (Board meeting date 04.07.2017 and number 09) and from the institution where the study was conducted. The purpose of the study was explained to 
the women who participated in the study and their oral consent was obtained.

\section{Statistical Analysis}

All data were analyzed with the Statistical Package for the Social Sciences program (version 24.0). The data were evaluated with number, percentage, $t$-test and variance analysis tests. Logistic regression analysis was performed with variables affecting women's Pap smear test status. Statistical significance level was considered as $\mathrm{p}<0.05$.

\section{Results}

The average age of women was $39.5 \pm 9.02$ years and $50.0 \%$ were $\geq 40$ years old. Of the participants, $59.2 \%$ stated that they had a Pap smear test. Of them, $60.8 \%$ were undergraduate or postgraduate. Of women, $11.7 \%$ had sufficient knowledge about early detection methods of cervical cancer and $42.5 \%$ had regular gynecological examinations (Table 1). The mean scores of the

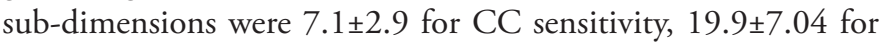
$\mathrm{CC} /$ seriousness, $31.9 \pm 7.2$ for Pap smear benefit and motivation, $8.9 \pm 3.2$ for CC health motivation and $30.1 \pm 10.1$ for Pap smear barriers (Table 2).

Women with a family history of cervical cancer and high income status had a higher CC sensitivity sub-dimension score without a statistically significant difference $(\mathrm{p}<0.05)$. Women with adequate knowledge of early diagnosis methods had higher Pap smear benefit and motivation sub-dimension scores with a statistically significant difference $(\mathrm{p}<0.001)$. Benefit and sensitivity subdimension scores were significantly lower $(\mathrm{p}<0.01)$, while Pap smear barrier scores were significantly higher $(\mathrm{p}<0.05)$ in high school and associate degree graduates than in undergraduates and postgraduates. The mean score of CC health motivation sub-dimension of the scale was found to be significantly higher in women who were undergraduate or postgraduate and who had adequate knowledge of early diagnosis. Pap smear barriers sub-dimension scores were significantly higher in women with high school and associate degree education and who did not have regular gynecological examinations $(\mathrm{p}<0.001)$ (Table 2$)$.

In Table 3, the factors that are effective in the behavior of Pap smear testing and the degree of effect are shown by the logistic regression model. It was determined that no sub-dimensions of the scale affected the behavior of Pap smear testing ( $p>0.05)$. While women's knowledge on gynecologic cancer and gynecological examinations increased Pap smear behavior by three times on average, women's age increased Pap smear behavior by about one fold.

\section{Discussion}

In this study, women's Cervical Cancer and Pap Test Health Belief Model scale lower size score averages were determined at moderate levels. The average scores of women with higher education levels in studies conducted in different educational groups are consistent with our study $(8,9,14-17)$. A study in educated women in West Africa (2014) highlighted the necessity of education about cervical cancer even if women were knowledgeable and educated (12). Health protective behaviors for cervical cancer in women with high levels of education were lower than expected. Regardless of women's educational status, positive health behaviors for cervical cancer and Pap smear testing should be increased.

In this study, women's perception of CC sensitivity was influenced by their good income status. These variables were thought to be effective in accessing information. Income status was not found to be effective in other sub-dimensions which only affected sensitivity perception in our study. Women with good income may have easier access to health care. Ersin et al. (9) stated that no variables affected sensitivity perception in female health care personnel. Another variable that affects women's perception of CC sensitivity is the presence of a history of CC in the family.

Table 1. Distribution of women by their characteristics

\begin{tabular}{|c|c|c|}
\hline Characteristics & Number & $\%$ \\
\hline \multicolumn{3}{|l|}{ Age group } \\
\hline 20-29 years & 19 & 15.8 \\
\hline 30-39 years & 41 & 34.2 \\
\hline 40 years or above & 60 & 50.0 \\
\hline Mean age & $39.5 \pm 9.02$ & \\
\hline \multicolumn{3}{|l|}{ Education level } \\
\hline $\begin{array}{l}\text { High school and associate } \\
\text { degree }\end{array}$ & 47 & 39.2 \\
\hline Graduate & 73 & 60.8 \\
\hline \multicolumn{3}{|l|}{ Income } \\
\hline Income=expense & 57 & 47.5 \\
\hline Income<expense & 45 & 37.5 \\
\hline Income>expense & 18 & 15.0 \\
\hline \multicolumn{3}{|l|}{ Cigarette smoking } \\
\hline Yes & 31 & 25.8 \\
\hline No & 89 & 74.2 \\
\hline \multicolumn{3}{|c|}{$\begin{array}{l}\text { Knowledge of early diagnosis } \\
\text { methods }\end{array}$} \\
\hline Sufficient & 14 & 11.7 \\
\hline Low & 73 & 60.8 \\
\hline None & 33 & 27.5 \\
\hline \multicolumn{3}{|c|}{$\begin{array}{l}\text { Having a history of cervical } \\
\text { cancer in family }\end{array}$} \\
\hline Yes & 4 & 3.3 \\
\hline No & 116 & 96.7 \\
\hline \multicolumn{3}{|c|}{ Status of Pap smear testing } \\
\hline Yes & 49 & 40.8 \\
\hline No & 71 & 59.2 \\
\hline \multicolumn{3}{|l|}{$\begin{array}{l}\text { Regular gynecological } \\
\text { examination }\end{array}$} \\
\hline Yes & 51 & 42.5 \\
\hline No & 69 & 57.5 \\
\hline Total & 120 & 100.0 \\
\hline
\end{tabular}


Table 2. Comparison of women's health belief model scale scores with different variables Scale sub-dimentions

\begin{tabular}{|c|c|c|c|c|c|c|c|c|c|c|}
\hline \multicolumn{11}{|l|}{ Education status* } \\
\hline \multicolumn{11}{|l|}{$\mathrm{Age}^{* *}$} \\
\hline $\begin{array}{l}20-29 \text { years } \\
30-39 \text { years } \\
40 \text { years or over }\end{array}$ & $\begin{array}{l}6.9 \pm 2.6 \\
7.4 \pm 2.7 \\
7.0 \pm 3.0\end{array}$ & 0.26 & $\begin{array}{l}20.2 \pm 5.6 \\
19.2 \pm 7.4 \\
20.3 \pm 7.2\end{array}$ & 0.75 & $\begin{array}{l}34.2 \pm 5.8 \\
31.0 \pm 7.8 \\
31.9 \pm 7.1\end{array}$ & 0.26 & $\begin{array}{l}8.3 \pm 3.3 \\
8.6 \pm 3.0 \\
9.2 \pm 3.4\end{array}$ & 0.46 & $\begin{array}{l}31.3 \pm 8.3 \\
30.9 \pm 12.0 \\
29.3 \pm 9.2\end{array}$ & 0.62 \\
\hline \multicolumn{11}{|l|}{ Income** } \\
\hline $\begin{array}{l}\text { Income=expense } \\
\text { Income<expense } \\
\text { Income>expense }\end{array}$ & $\begin{array}{l}7.5 \pm 2.8 \\
6.2 \pm 2.9 \\
7.8 \pm 2.5\end{array}$ & 0.03 & $\begin{array}{l}20.8 \pm 6.5 \\
18.0 \pm 6.8 \\
21.9 \pm 8.5\end{array}$ & 0.06 & $\begin{array}{l}33.3 \pm 5.1 \\
31.0 \pm 8.3 \\
29.9 \pm 9.1\end{array}$ & 0.11 & $\begin{array}{l}8.9 \pm 3.1 \\
9.0 \pm 3.7 \\
8.5 \pm 2.7\end{array}$ & 0.85 & $\begin{array}{l}30.5 \pm 9.5 \\
29.3 \pm 10.3 \\
31.5 \pm 11.7\end{array}$ & 0.70 \\
\hline \multicolumn{11}{|c|}{ Knowledge of early diagnosis methods ** } \\
\hline $\begin{array}{l}\text { Sufficient } \\
\text { Low } \\
\text { None }\end{array}$ & $\begin{array}{l}7.8 \pm 3.8 \\
7.3 \pm 2.6 \\
6.5 \pm 2.9\end{array}$ & 0.28 & $\begin{array}{l}20.3 \pm 7.5 \\
20.2 \pm 6.6 \\
19.0 \pm 7.9\end{array}$ & 0.70 & $\begin{array}{l}35.3 \pm 3.5 \\
32.7 \pm 6.1 \\
28.8 \pm 9.3\end{array}$ & 0.00 & $\begin{array}{l}10.6 \pm 2.9 \\
9.0 \pm 2.9 \\
7.7 \pm 3.7\end{array}$ & 0.01 & $\begin{array}{l}25.4 \pm 12.3 \\
30.0 \pm 8.9 \\
32.4 \pm 11.0\end{array}$ & 0.09 \\
\hline \multicolumn{11}{|c|}{ Having a history of cervical cancer in family * } \\
\hline $\begin{array}{l}\text { Yes } \\
\text { No }\end{array}$ & $\begin{array}{l}10.5 \pm 2.4 \\
7.0 \pm 2.8\end{array}$ & 0.01 & $\begin{array}{l}24.0 \pm 4.5 \\
18.8 \pm 7.0\end{array}$ & 0.16 & $\begin{array}{l}36.0 \pm 3.1 \\
31.8 \pm 7.3\end{array}$ & 0.06 & $\begin{array}{l}8.2 \pm 1.7 \\
8.9 \pm 3.2\end{array}$ & 0.69 & $\begin{array}{l}23.5 \pm 9.8 \\
30.4 \pm 10.0\end{array}$ & 0.18 \\
\hline
\end{tabular}

Jia et al. (18) found that women with a family history of cancer had higher levels of knowledge about CC. Although having a history of cancer in the family has a positive impact on women's susceptibility to CC and it affects knowledge levels positively; education and monitoring of these women who are in the high risk group should be carried out more carefully. Perceptions of women of not being at risk for cervical cancer may hamper their approach to early diagnosis practices. Increasing CC sensitivity can positively affect Pap smear behavior. Therefore, effective training should be considered. Kissal and Baser (10) stated that the training given by nurses based on HBM was effective in raising the sensitivity and perception of benefits of CC.

In our study, it was determined that the variables that were examined did not affect the CC seriousness sub-dimension. Contrary to our study, Koç et al. (17) stated that education increased the severity of CC. Interestingly, in this study, although all women had a high level of education, they did not take the disease seriously and ignored it. Women will also not find it meaningful to participate in cancer screening studies if they do not take the disease seriously.

In this study, the score of women who only had knowledge about early diagnosis was higher in the area of pap smear benefit and motivation. Although women had a high level of education, the fact that only those who had knowledge had different perceptions of benefits suggested that all women needed to increase their level of knowledge. If the individual has information about the disease, his/her perception is affected accordingly (19). Studies highlight that women's high benefit perception is effective in getting a Pap smear test $(20,21)$. The high perceived benefit indicates the importance of the screening method and the perception of a program (21). Jia et al. (18) showed that cervical cancer knowledge was associated with women's participation in cervical cancer screening. The benefit and motivation of Pap smears were determined higher in women who graduated from 
Table 3. Regression analysis of factors associated with pap test

\begin{tabular}{|c|c|c|c|c|c|c|c|}
\hline \multirow[b]{2}{*}{ Variables } & \multirow[b]{2}{*}{$\beta(\mathrm{SE})$} & \multirow[b]{2}{*}{$\begin{array}{l}\text { Wald } \\
\text { statistic }\end{array}$} & \multirow[b]{2}{*}{ Df } & \multicolumn{4}{|c|}{$95 \% \mathrm{Cl}$ for odds ratio } \\
\hline & & & & $p$ & $\begin{array}{l}\text { Odds } \\
\text { ratio }\end{array}$ & Lower & Upper \\
\hline Age & $\begin{array}{l}-.099 \\
(.028)\end{array}$ & 12.695 & 1 & .000 & .906 & .858 & .957 \\
\hline Regular gynecological examination & $\begin{array}{l}1.118 \\
(.504)\end{array}$ & 4.912 & 1 & .027 & 3.059 & 1.138 & 8.221 \\
\hline Knowledge of early diagnosis methods & $\begin{array}{l}1.103 \\
(.472)\end{array}$ & 5.465 & 1 & .019 & 3.015 & 1.195 & 7.603 \\
\hline Pap smear benefit and motivation & $\begin{array}{l}-.043 \\
(.035)\end{array}$ & 1.512 & 1 & .219 & .958 & .894 & 1.026 \\
\hline Pap smear barriers & $\begin{array}{l}.007 \\
(.025)\end{array}$ & .070 & 1 & .792 & 1.007 & .958 & 1.058 \\
\hline Seriousness & $\begin{array}{l}.010 \\
(.037)\end{array}$ & .071 & 1 & .791 & 1.010 & .940 & 1.085 \\
\hline Sensitivity & $\begin{array}{l}.007 \\
(.091)\end{array}$ & .005 & 1 & .941 & 1.007 & .843 & 1.202 \\
\hline Health motivation & $\begin{array}{l}-.060 \\
(.077)\end{array}$ & .604 & 1 & .437 & 942 & .810 & 1.095 \\
\hline Constant & $\begin{array}{l}3.874 \\
(1.797)\end{array}$ & 4.644 & 1 & .031 & & & \\
\hline
\end{tabular}

college, had an occupation and worked, had knowledge of Pap testing, and had a history of gynecologic cancer in the family in the study by Egelioglu Cetisli et al. (8). Increasing perceptions and knowledge of cervical cancer benefit will be effective in increasing women's likelihood of taking preventive action. Athome monitoring and training by medical staff affects women's level of knowledge about cervical cancer (22).

Women's willingness to have cervical cancer screenings reveals their health motivations. In our study, only high level of education and knowledge of early diagnosis affected the perception of health motivation. In addition to their results supporting the findings of our study, Egelioglu Cetisli et al. (8) showed that the working condition of women was also effective. Koç et al. (17) showed that education given raised women's perception of health motivation and increased their tendency to perform screening behavior. Women should be empowered by effective training in increasing women's health motivations and ensuring their willing participation in screening behaviors. According to the Health Belief Model, as women's positive perception of the usefulness of the Pap smear test increases, sensitivity, seriousness and health motivation increase in parallel (23).

In this study, the barrier perception score of educated women was moderate. Studies in Turkey found that among the barriers to screening cervical cancer were ignorance, neglect, shame, fear of cancer and death, lack of Social Security, thinking that they were not a risky group, presence of transportation difficulties, inability to go to the doctor without permission from their spouses and inability to be examined by a male doctor $(17,24,25)$. In other studies in the literature, reasons similar to the perceptions of barriers in our country were expressed $(18,21,26,27)$. Gokgoz et al. (16), showed that women with educational attainment of high school and university had lower perceptions of barrier than other educational groups. In this study, women who did not have regular gynecological examinations and who had lower educational levels had significantly higher perception of barrier. Women who do not have regular gynecological examinations may be the result of the perception of Pap test barrier in the literature. Medical staff should therefore question the causes that hinder women's screening behaviour and provide approaches to eradicating it. Screening behaviors for CC can be increased when the perception of disability is reduced or eliminated. Studies of CC and HPV prevalence and educational efforts highlighting the medical importance of screening can reduce stigma and barriers to Pap testing for CC and screening (28).

In our country, national based cervical cancer screening has been conducted more systematically and free of charge in recent years (6). In our study, more than half of women had Pap tests, but cervical cancer and Pap test beliefs were not sufficient. Women who participated in our study may also have had Pap testing under the screening program. One study highlighted that women had little awareness of CC and had negative judgments and beliefs about screening methods (9). In order to gain knowledge of CC 
and Pap smear test behaviors, education of women with high levels of education should also be considered.

In this study, age variable increased women's Pap smear test behavior approximately by one fold, while early diagnosis information and gynecological examination increased it by 3 folds. Similar to our study results, Jeihooni et al. (21) determined that age and knowledge were effective variables in performing Pap smear test by women. Ma et al. (29) showed that age and education were effective variables in pap smear screening behaviors. Our study and other studies showed that Pap testperforming behaviors increased as age increased (29). The emergence of gynecological problems in women with age can lead to increased fear and anxiety and to screening behaviors. Lack of information is an important factor affecting Pap smear test behavior. Gokgoz et al. (16) determined that women's knowledge of why a Pap smear test was performed affected their behavior by having a Pap smear test. In this study, it was also determined that the attitudes of women regarding gynecological examination influenced the behavior of having a Pap smear test (16). The socio-demographic characteristics of women are important in the behavior of having Pap smear tests. However, adoption of preventative behaviors depends not only on external factors, but also subjective factors towards women (30). All these features should be taken into account in increasing the rates of women having Pap smear tests.

In regression analysis, none of the sub-dimensions of the scale affected women's Pap testing. Similarly, in the study of female health personnel; sensitivity, seriousness and benefit perceptions were not found to be effective in Pap smear testing (9). Unlike our work, Jeihooni et al. (21) showed positive association between SIM structures and Pap test performance. Ma et al. (29) showed that, in terms of the perceived benefits of pap smear test, approximately $50 \%$ of women believed that Pap testing was the best way to detect CC and that it was important, and that women who believed them were two to four times more likely to have a Pap test than those who did not believe. TannerSmith and Brown (23) found that perceived benefits and barriers were the strongest determinants of participation in screening behaviors. Increasing women's health beliefs about CC and Pap testing will also affect their participation in screening behaviors. Studies in the literature highlight that trainings based on the Health Belief Model increase participation in CC screening programs $(10,17,22,26,27,31)$. Health personnel should carry out planned training activities in all areas where health services are provided in an orderly manner. However, considering that working women cannot come to receive education and do not have the time, planned training activities can be carried out in their fields of study.

\section{Conclusion}

As a result, awareness of CC and Pap smear test were not enough in working women with high level of education. In our study, the score averages of the sub-dimensions of the HBM scale were moderate. These women's perceptions of CC usefulness, sensitivity, seriousness, and the Pap smear test health motivation average scores should be increased and the Pap test barrier perception average scores should be lowered. It is thought that improving awareness of cancer prevention will be effective in ensuring the effectiveness of screening programmes, no matter what level of education women are at. All health workers play an important role in preventing CC, providing effective and accurate information. In particular, nurses are effective in providing health education that will affect women's screening behavior and in increasing women's motivations. Planned training programs should be conducted continuously for women in work environments and wherever they come to receive health care. Training educated women is suggested by the idea that they may be role models in society.

\section{Ethics}

Ethics Committee Approval: Approval was obtained from the Non-interventional Clinical Research Ethics Committee of a University (Board meeting date 04.07.2017 and number 09) and from the institution where the study was conducted.

Informed Consent: The purpose of the study was explained to the women who participated in the study and their oral consent was obtained.

Peer-review: Externally peer reviewed.

\section{Authorship Contributions}

Concept: İ.Ö.Ç., Design: İ.Ö.Ç., Data Collection or Processing: İ.Ö.Ç., E.K., Analysis or Interpretation: İ.Ö.Ç., E.K., Literature Search: İ.Ö.Ç., E.K., Writing: İ.Ö.Ç., E.K.

Conflict of Interest: No conflict of interest was declared by the authors.

Financial Disclosure: No financial support was received for this study.

\section{References}

1. Kanbur A, Çapık C. Servikal Kanserden Korunma, Erken TanıTarama Yöntemleri ve Ebe/Hemşirenin Rolü. Sağlık Bilimleri Fakültesi Hemşirelik Dergisi 2011:61-72.

2. World Health Organization. Human papillomavirus (HPV) and cervical cancer. http://www.who.int/mediacentre/factsheets/fs380/ en/. Erişim Tarihi: 18Mart 2018.

3. Ferlay J, Soerjomataram I, Dikshit R, Eser S, Mathers CI, Rebelo M, et al. Cancer incidence and mortality worldwide: Sources, methods and major patterns in GLOBOCAN 2012. Int J Cancer 2015;136:359-86.

4. Türkiye Halk Sağlığı Kurumu, Kanser Daire Başkanlığı 2014 Yılı Türkiye kanser 1statistikleri [Internet] Ankara: Türkiye Halk Sağlığı Kurumu; 2016. [cited 2017 Apr 11]. url:http://kanser. gov.tr/daire-faaliyetleri/kanser-istatistikleri/2106-2014-yl1-türkiyekanser istatistikleri.html

5. Gültekin M, Akgül B. HPV screening in Islamic countries. Lancet Infect Dis 2017;17:368.

6. Gültekin M, Dundar S, Kucukyildiz I, Karaca Zayifoğlu M, Boztaş G, Turan SH, et al. Survival of gyne1 cological cancers in Turkey: where are we at? J Gynecol Oncol 2017;28:85. 
7. Taşcı Duran E, Koc S, Korkmaz M. Turkish Social Attitudes towards to Cancer Prevention: a Health Belief Model Study. Asian Pac J Cancer Prev 2014;15:7935-40.

8. Egelioğlu Çetişli N, Top ED, Işık G. Cervical Cancer and Pap Smear Test Health Beliefs and Health Promoting Lifestyle of Women in Turkey. IJCS 2016;9:630-9.

9. Ersin F, Kissal A, Polat P, Koca BD, Erdoğan M. Perception Of Female Medical Personnel Toward Cervical Cancer And The Affecting Factors, HEMAR-G 2016;18:31-43.

10. Kıssal A, Beşer A. Results of breast and cervical cancer Health Promotion Model for older Turkish women. Journal of Human Sciences 2017;14:2374-85.

11. Bebiş H. Sağlığın Geliştirilmesi ile ilgili Modeller. İçinde: Alkaya AS. editör. Sağlığın Geliștirilmesi. Ankara: Hedef Yayıncılık Matsa Basımevi, I. Baskı; 2017:47-61.

12. Moore AR, Driver N. Knowledge of Cervical Cancer Risk Factors Among Educated Women in Lomé, Togo: Half-Truths and Misconceptions. SAGE Open 2014:1-8.

13. Güvenc G, Akyuz A, Açikel CH. Health belief model scale for cervical cancer and Pap Smear test: psychometric testing. J Adv Nurs 2011;67:428-37.

14. Demirtas B, Acikgoz I. Promoting attendance at cervical cancer screening: understanding the relationship with Turkish women"s health beliefs. Asian Pac J Cancer Prev 2013;14:333-40.

15. Bal MD. Evaluation of Women Having Pap Smear Test by Health Belief Model Scale. MÜSBED 2014;4:133-8.

16. Gökgöz N, Aktaş D. Determination of women awareness level of cervical cancer \& conducting Pap-smear test. Yıldırım Beyazıt University Faculty of Health Sciences Nursing E-Journal 2015;3:1123.

17. Koç Z, Özdeş EK, Topatan S, Çinarli T, Şener A, Danaci E, Palazoğlu CA. The Impact of Education About Cervical Cancer and Human Papillomavirus on Women's Healthy Lifestyle Behaviors and Beliefs: Using the PRECEDE Educational Model. Cancer Nurs 2019;42:106-18.

18. Jia Y, Li S, Yang R, Zhou H, Xiang Q, Hu T, et al. Knowledge about cervical cancer and barriers of screening program among women in wufeng county, a high-incidence region of cervical cancer in China. PLoS One 2013;8:e67005.

19. Erci B. Halk Sağlığı Hemşireliği Kitabı. İkinci baskı. Ankara: Nobel Tip Kitapevi; 2016.
20. Lee EE, Fogg L, Menon U. Knowledge and Beliefs Related to Cervical Cancer and Screening Among Korean-American Women. West J Nurs Res 2008;30:960-74.

21. Jeihooni AK, Kashfi SM, Bahmandost M, Kashfi SH. The Survey of Factors Affecting Pap Smears Based on Health Belief Model in Health Centers in Fas'a, Fars Province, Iran. Women's Health Bull 2015;2:e25565.

22. Kolutek R, Aydın Avcı İ. The Effect of Training and Monitoring at Home on the Knowledge Level and Practices of Married Women Regarding Breast and Cervical Cancer. J Breast Health 2015;11:155-62.

23. Tanner Smith EE, Brown TN. Evaluating the Health Belief Model: A critical review of studies that predict mammography and pap screening. Social Theory \& Health 2010;8: 95-125.

24. Ersin F, Bahar Z. Effects of health promotion models on breast cancer early detection behaviors: A literature review. DEUHYO ED 2012;5:28-38.

25. Aydoğdu NG, Bahar Z. The Effects of Using Health Belief and Health Promotion Models in Low-Income Women with Regard to Breast and Cervical Cancer Early Detection Behaviour. DEUHYO ED 2011;4:34-40.

26. Parsa P, Sharifi F, Shobeiri F, Karami M. Effects of Group Counseling Based on Health Belief Model on Cervical Cancer Screening Beliefs and Performance of Rural Women in Kaboudrahang, Iran. Asian Pac J Cancer Prev 2017;18:1525-30.

27. Coronado Interis E, Anakwenze CP, Aung M, Jolly PE. Increasing Cervical Cancer Awareness and Screening in Jamaica: Effectiveness of a Theory-Based Educational Intervention. Int J Environ Res Public Health 2016:13.

28. Rees HD, Lombardo AR, Tangoren CG, Meyers SJ, Muppala VR, Niccolai LM. Knowledge and beliefs regarding cervical cancer screening and HPV vaccination among urban and rural women in León, Nicaragua. Peer J 2017;5:3871.

29. Ma GX, Gao W, Fang CY, Tan Y. Feng Z, Ge S, et al. Health Beliefs Associated with Cervical Cancer Screening Among Vietnamese Americans. J Womens Health (Larchmt) 2013;22:276-88.

30. Evangelista Rodrigues D, Alves Moreira KF, Souza de Oliveira T. Barriers to prevention of cervical cancer in the city of Porto Velho, Rondônia, Brazil. Invest Educ Enferm 2016;34;58-66.

31. Shobeiri F, Javad MT, Parsa P, Roshanaei G. Efficacy of Group Training Based on the Health Belief Model for Pap Smear Testing in Iranian Women: a Quasi-Experimental Study. Asian Pac J Cancer Prev 2016;17:2871-6. 